\title{
Torn between Cultures: Reading Shashi Tharoor's Riot
}

\author{
Athira M \\ PG Student \\ Govt. College \\ Mokeri, Kerala, India \\ snmeppad@gmail.com
}

\begin{abstract}
Shashi Tharoor is a distinctivevoice in the Postcolonial Indian literature in English with his remarkable contribution of more than 16 works of fiction and non-fiction. Postcolonialism refers to a set of theoretical concepts, approaches and interventions which deals with the diverse effects of the interaction between the colonizer and the colonized. History, politics and culture have always been a dominant preoccupation of the Indian English novelists. The compulsive obsession was perhaps inevitable since the genre originated and developed concurrently with the climatic phase of colonial rule. As a diplomat and writer, Shashi Tharoor has explored the diversity of culture in his native country. He has made his point in many of his interviews that the novel is full of collisions of various sorts- personal, political, cultural, emotional and violent. Riot is a novel about the ownership of history, about love, hate, cultural collision, religious fanaticism and the impossibility of knowing the truth. The novel chronicles the mystery of an American 24-year old lady, Priscilla Hart. The intention of this paper is to explore the cultural conflict between the East and the West and an attempt is made to examine Shashi Tharoor's Riot as a conveyor of the various distinguishable features to the divergent cultures. The characters of Riot are facing problems and striving to achieve their identities as Indians and as individuals in Indian society. Lakshman, though an educated
\end{abstract}


Indian, cannot share his intellectual ideas with any fellow Indians, but feels quite comfortable with Priscilla, an American lady. Yet, he cannot completely forego his Indian identity and is aware of their irreconcilable gap between their culture, values and outlook towards life.

Keywords: Cultural conflict, collision, Identity, Ideology, History

Shashi Tharoor is one of the significant voices in the Post-Colonial Indian English literature with his distinctive contribution of more than 16 works of fiction and non-fiction. He made his presence in the literary scenario in 1982 with the publication of Reasons of State. He has established himself as a novelist, politician, diplomat and Lok Sabha member in a short span of time and authored hundreds of columns and articles in dailies like The New York Times and The Washington Post and in magazines like TIME and Newsweek.

History, politics and culture have always been a dominant preoccupation of the Indian English novelists. It might be because of the climatic phase of colonial rule and the stirrings of nationalist sentiment. As a diplomat and writer, Tharoor has explored the diversity of culture in his native country. Culture, Colonialism, Hybridity, Identity, Nation, Politics and Religion have always seen as important aspects in his works. The novel, Riot has its concern with the multiple kinds of social, political and cultural affairs in various degrees. Tharoor himself has confessed that the novel is full of collisions of various sorts-personal, political, emotional and cultural:

Riot is a love story, while also being a hate story. That is to say, it is the story of two people intimately in love in a little district town in Uttar Pradesh, but it also a story of the smouldering hatreds being stroked in that town, Zalilgarh, and of the conflagration in which both are intimately caught up. American readers looking for a love story will also find a novel about the construction of identity, the nature of truth and the ownership of history; Indian readers 
expecting a novel about the dangers of communalism will also discover a tale of another kind of passion.(Bookless36-37)

Riot chronicles the mysterious death of Priscilla Hart, a twenty-four-year old American lady who has come to India for her research purpose and accidentally falls in love with an Indian district magistrate, Lakshman. Lakshman is an educated elite whose intelligence revealed through his communication with Priscilla slowly pays way for love. The novel mainly highlights the contrasting features of two Cultures- the Eastern and Western. The characters, especially Priscilla and Lakshman represents the attitudes of two different cultures towards love, sex and marriage. The characters of Riot are facing problems and striving to achieve their identities as Indians and as individuals in Indian society. Lakshman, though an educated Indian, cannot share his intellectual ideas with any fellow Indians, but feels quite comfortable with Priscilla, an American. Yet, he cannot completely forego his Indian identity and is aware of theirreconcilable gap between their culture, values and outlook towards life. Metaphorically, this is the conflict or clash between the East and West ideologies.

What should be regarded as the most striking aspect of this novel is that Tharoor gave preference to neither West nor East. Riot showcases the diversity of pluralistic India and its realities in the Post colonial era. Tharoor tries his best to maintain a balanced view by not being judgmental. And he does not put one role above the other. Thus, he succeeded in making Riot an unprejudiced novel.

The rioting cultures have been depicted through the affair of Lakshman and Priscilla. Love is the unifying element of both the cultures. Still, as the novel go further, it becomes evident that Priscilla is unconditionally in love with him. She is not actually concerned about the past of the character of her love, like many Indians. On the other hand, Lakshman is torn between his love for Priscilla and the feelings of responsibility towards his family. Moreover, 
Lakshman could not completely tolerate the fact that Priscilla had certain relationships before coming to India. He has been haunted by her past: "It was not lightness I felt at her revelations. I had known all along that her life must have been something like this, an American Life" (82).Lakshman goes through the loss of selfhood and insecurity because he is unable to accept Priscilla, being a married man. What makes him more concerned is not his wife, but his daughter. He is the one who is torn between Cultures and is torn between the choice of the inherited and preferred culture. Despite his best efforts, he remains knitted to the Indian culture.

The differentia that one could find in the concept of physical love in Riotspeaks volumesof the cultural diversity. India has a unique concept of sex as a sacred thing, indulged to create progeny, and a concealed activityin the personal domain, taboo enough to go for a public debate. Majority consider it as part of their integrity to the spouse, unlike the West where it something quite personal.Lakshman attempts to remain normal to the questionshe asks him; "You didn't expect me to be virgin, did you?"(83), but reveals his reservations: Until Priscilla, I had never really known the pleasure of sex. Geetha lies stiffly, unmoving as I go about what she sees as my business; she neither initiates nor welcomes, making it clear that she understands her amatory role as being to endure rather than to enjoy. She is not one for much foreplay, and she is often still dry when I enter her, her eyes tightly shut, her face contorted in something approaching a grimace. When it is over, I move quickly off her, lightened by no great sense of satiation. She turns away from me, her duty done. Not surprisingly, we make love less and less frequently. Since Priscilla entered my life, I have slept with Geetha just once. Neither of us misses it.(156) 
The institution of marriage is perceived through Western and Easternstand points with Lakshman and Priscilla. In India, marriage is not a union of two individuals but of two families and is pompously celebrated. Marriage in the West is coming together of two people which is more of an individual decision with or without any ceremony.Riot showcases Lakshman, along with others being caught in the Indian consideration of marriage as an obligation to the parents, part of the duties of a good son. "In America think of marriage as two people loving each other and wanting to be together. We in India see marriage as an arrangement between families, a means of perpetuating the social order... Love is supposed to come after marriage"(153). Another aspect that really needs a special consideration is that in India, it should be marriage that leads to sex and then love. For Westerners, it is love that leads to sex and marriage is a final step which they need each other's complete consent and they must know each other well.

Nandni, the secretary of Rudyard Hart,is another character who had to accommodate the advances made by the boss at the workplace. Though Nandni and Priscilla belong to two different contexts, Nandni obviously anticipates Priscilla and often functions as a foil to her. Both Nandni and Priscilla, being courted by a married man, later get abandoned as sacrificial objects. Thereseems to be a wide gulf towards the attitude to love and sex betweenLakshman and Priscilla. As Priscilla puts it: "Through sex, he found love, and in love he found confusion, uncertainty, fear. Whereas I loved him from almost the first moment and felt nothing but certainty about him. The sex was just a means of expressing my love, a way of giving myself to the man I loved. I'm not sure that he ever understood the difference."(242) Tharoor not only exploresthe East-West cultural collisions, but the cultural diversity within India as well. Fatima Bi and Sundari are the best examples to showcase the condition of women in a patriarchal society.Tharoor is successful in portraying the clash between basic Indian cultural attitudes and the effects of Western influence and educationin India. Despite 
suchan influence and Western education, Indian belief systemlargely remains committed to its tradition. 


\section{Works Cited}

Parmar, D Bhavesh, “The Reflection of Indianness in Shashi Tharoor's

works".www.raijmr.com

Sharma, Dev Kanth, "Representation of conflict between East and West through the relationship of Lakshman and Priscilla in Shashi Tharoor's Riot", http://www.ijelr.in, January-March 2016.

Tharoor, Shashi. Bookless in Baghdad; Arcade Publishing, 2005.

---. Riot, A Novel: Penguin, 2001. 